\title{
Nephrotoxicity of High-Dose Gadolinium Compared with Iodinated Contrast
}

\author{
Martin R. Prince, M.D., Ph.D. • Christina Arnoldus, M.D. • Joan K. Frisoli, Ph.D.
}

To determine if high-dose gadolinium chelates are less nephrotoxic than iodinated contrast. Records of 342 patients who had received high-dose gadolinium (.2 to $.4 \mathrm{mmol} / \mathrm{kg}$ ) for magnetic resonance imaging were reviewed to identlfy patients who had alco recelved todinated contrast for radiographic examinations. Their clinical course and laboratory data were reviewed to Identify changes in serum creatinine attributable to the contrast agents. In 64 patients, seruim creatinine data were available pre and post both gadolinium and lodinated contrast. The mean change in serum creatinine after gadoliniom in these 64 patients was -.07 $\mathrm{mg} / \mathrm{dL}(-6 \mu \mathrm{mol} / \mathrm{L})$. By comparison, the mean change in serum creatinine in the same patients after lodinated contrast was $.35 \mathrm{mg} / \mathrm{dL}(+31 \mu \mathrm{mol} / \mathrm{L})$ from 2.0 \pm 1.4 to $2.3 \pm 1.8(P=.002)$. Eleven of the 64 patients had iodinated contrast-induced renal failure $[.5 \mathrm{mg} / \mathrm{dL}$ or greater rise in serum creatinine); none had gadolinium contrast-induced renal fallure deepite the high gadolinium dose and high prevalence of underlying renal insufficiency. High-dose gadolinium chelates are significantly less nephrotodic than iodinated contrast.

Index termp Gadolinium + Angiography • lodine * Renal - Kidncy * Hypertension

JMII 1986: 1:162-166

Abbrevintlons: MRI = magnetic resonance imaging, $M R=$ magnetic resonance, $\mathrm{CT}=$ computed tomography.

From the Department of Radlology. University of Mlchigan Hospitals. UHB2B31IG. Ann Arbor, MI 48109-0030; and Massachusetts General Hospital. Boston, MA- Recetwed Decemher 12, 1994; revision requested March 2, 1995; revision recelved April 11; accepted April 11. Supported by Grant HL46384 from the National Heart, Lung, and Flood Institute and by the Radiologlcal Soclety of North America Research and Education Fund. Address reprint request to M.R.P.

D ISMRM. 1996
THERE IS EVIDENCE from animal experiments that gadolinium chelates can be associated with vacuolization of proximal tubular cells and increased excretion of urinary enzymes, suggesting the possibility of damage to the nephron $(1,2)$. Clinical experience with gadolinium chelates, however, has shown them to be free of observable human nephrotoxicity (3-13). As a result, gadolinium-enhanced magnetic resonance imaging (MRI) is increasingly substituted for iodinated contrast examinations in patients at risk for iodinated contrast-induced nephrotoxicity. Many of these human toxicity studies have been conducted on normal volunteers, on patfents with normal renal function, and at low doses. But gadolinium chelates are now being used in seriously ill patients, in patients with renal insufficiency (14), and at larger and larger doses $(15,16)$. These trends might be expected to unmask any intrinsic nephrotoxicity of these gadolinium chelates. In addition, there has been no direct comparison of gadolinium and iodinated contrast to demonstrate with statistical significance that gadolinium really is less nephrotoxic than iodinated contrast.

The goal of this study was to determine if gadolinium chelates are significantly less nephrotoxic than lodinated contrast at high doses in the patient population in whom they are routinely used.

\section{- METHODS}

Medical records of 342 consecutive patients at Massachusetts General Hospital (July 1992 to June 1993) and the University of Michigan Hospitals (September 1993 to January 1995) who underwent aortic, pelvic, or renal artery magnetic resonance (MR) anglography with highdose gadolinium (.2 to $.4 \mathrm{mmol} / \mathrm{kg}$ ) were reviewed retrospectively to Identify patients who may have had contrast-induced renal failure. Patients included 190 males and 152 females, ranging in age from 4 to 87 years, with a mean age of 62 years. Eighty-six of the 342 patients (25\%) had documented baseline renal insufficiency, with a serum creatinine level $>1.5 \mathrm{mg} / \mathrm{dL}$. Primary indications for the MR examinations included hypertension, renal insufficiency, abdominal aortic aneurysm. and peripheral vascular disease.

All patient medical records were reviewed to identify serum creatinine levels pre- and postadministration of gadolinium contrast. Patients who did not have serum creatinine data within 2 days before and 2 days postgadolinium were excluded from further analysis. The change in serum creatinine level with gadolinium was 
Table 1

Effect of High-Dose Gadolinium on Serum Creatinine

\begin{tabular}{|c|c|c|c|c|c|}
\hline \multirow[b]{3}{*}{ Gadolinium Chelate } & \multirow{3}{*}{$\begin{array}{c}\text { No. of Patients } \\
\text { Reviewed }\end{array}$} & \multirow{3}{*}{$\begin{array}{l}\text { No. of Patients } \\
\text { with Serum } \\
\text { Creatinine Data }\end{array}$} & \multicolumn{2}{|c|}{ Serum Creatinine $(\mathrm{mg} / \mathrm{dL})$} & \multirow[b]{3}{*}{ Delta } \\
\hline & & & \multicolumn{2}{|c|}{ Mean $\pm \mathrm{SD}$ (Minimum-Maximum) } & \\
\hline & & & Pre & Post & \\
\hline $\begin{array}{l}\text { Gadopentetate } \\
\text { dimeglumine }\end{array}$ & 92 & $37(52)^{*}$ & $\begin{array}{c}2.44 \pm 1.55 \\
(.7-6.4)\end{array}$ & $\begin{array}{c}2.33 \pm 1.46 \\
(.7-5.7)\end{array}$ & $\begin{array}{c}-. .11 \\
(-.7-.4) \dagger\end{array}$ \\
\hline Gadodiamide & 213 & $67(82)^{*}$ & $\begin{array}{c}2.09 \pm 1.62 \\
(.5-7.1)\end{array}$ & $\begin{array}{c}2.04 \pm 1.54 \\
(.6-7.0)\end{array}$ & $\begin{array}{c}-.05 \\
(-.7-.4) \dagger\end{array}$ \\
\hline Gadoteridol & 37 & $6(9)^{*}$ & $\begin{array}{c}1.78 \pm .46 \\
(1.2-2.5)\end{array}$ & $\begin{array}{c}1.81 \pm .47 \\
(1.2-2.6)\end{array}$ & $(-.1-.1) \dagger$ \\
\hline Total & 342 & $110(143)^{*}$ & $\begin{array}{c}2.20 \pm 1.56 \\
(.5-7.1)\end{array}$ & $\begin{array}{c}2.13 \pm 1.48 \\
(.6-7.0)\end{array}$ & $\begin{array}{c}-.07 \\
(-.7-.4)+\end{array}$ \\
\hline
\end{tabular}

- Includes patients on dialysis (4), patients who received gadolinium and iodinated contrast on the same day (10), and patients with rising serum creatinine at the time of MR angiography caused by recent aortic surgery (5), iodinated contrast-induced renal failure (7), hypotension or dehydration (6), or renal transplant rejection (1).

+ Values in parentheses are maximum decrease and maximum increase.

calculated by subtracting the pregadolinium serum creatinine from the first postgadolinium serum creatinine. If the serum creatinine level began rising within 2 days after the gadolinium administration, then the peak level attained during the 7 days postgadolinium was considered to be the post-gadolinium creatinine level for purposes of calculating the change in serum creatinine. The type and dose of gadolinium used for each patient were recorded.

Medical records were also reviewed to identify the date of any study in which each of these patients may have also received iodinated contrast, including cardiac catheterization, angiography, intravenous pyelography, or contrast-enhanced computed tomography (CT). Data on serum creatinine levels within 2 days pre- and postiodinated contrast were also reviewed, and the change in serum creatinine after iodinated contrast was calculated in exactly the same manner as used with the gadolinium contrast.

Data from patients who received gadolinium and iodinated contrast within a 48-hour interval were included only if serum creatinine data were available in between the two studies (eight patients). Data from patients who received gadolinium and iodinated contrast on the same day (10 patients) or who were on dialysis (4 patients) were excluded. Data from patients whose renal function was unstable at the time of imaging were also excluded (19 patients). These included five patients who were unstable postaortic surgery, seven patients with iodinated contrast-induced renal failure at the time of MRI, six patients with hypotension/dehydration, and one patient subsequently shown to have renal transplant rejection.

Patients who received iodinated contrast received a variety of types of both ionic and nonionic iodinated contrast, including sodium diatrizoate (hypaque), meglumine iothalamate (conray), sodium/meglumine diatrizoate (renografin), sodium/meglumine ioxaglate (hexabrix), iohexol (omnipaque), and iopamidol (isovue). Many patients received more than one type of iodinated contrast during a single examination. The choice of iodinated contrast agent (ionic versus nonionic) was based partly on the goal of maximizing patient safety and partly on the personal preference of the radiologist or cardiologist doing the procedure. The typical lodinated contrast doses were $60 \mathrm{~g}$ of iodine for an aortogram and runoff, $30 \mathrm{~g}$ of iodine for a renal arteriogram, 40 to $50 \mathrm{~g}$ of iodine for CT scans, and $50 \mathrm{~g}$ of iodine for a cardiac catheterization examination. The exact dose of iodinated contrast used for each patient was not documented in sufficient detail to allow stratification of the data into different iodinated contrast doses.
The three types of gadolinium chelates used included gadopentetate dimeglumine (Magnevist, Berlex Laboratories, Wayne, NJ), gadodiamide (Omniscan, Nycomed, Princeton, NJ), and gadoteridol (ProHance, Bracco, Princeton, NJ). The choice of gadolinium contrast agent was based on the compound in stock at the time of imaging and was not made on the basis of any patient characteristics. Gadolinium was administered in combination with a saline flush in all cases and in most cases in combination with 150 to $250 \mathrm{ml}$ of fluid via an intravenous line.

\section{Statistical Analysis}

The significance of changes in serum creatinine after gadolinium contrast and iodinated contrast was calculated with Student's $t$ test for paired data. Student's $t$ test for paired data was also used to determine if the mean change in serum creatinine with gadolinium was significantly different than the mean change in serum creatinine with iodinated contrast. This statistical analysis was then repeated for the subgroup of patients who had renal insufficiency. It was repeated for the subgroups of patients corresponding to those who received each of the three different gadolinium chelates. All calculations were performed on a computer (Macintosh Quadra 700, Apple Computer, Cupertino, CA) using a spreadsheet program (Excel Version 4.0, Microsoft, Seattle, WA).

\section{- RESULTS}

Review of 342 patients who received high-dose gadolinium $(.2$ to $.4 \mathrm{mmol} / \mathrm{kg})$ identified 143 patients who had serum creatinine data within 2 days pre- and postgadolinium. Thirty-three of these patients were excluded because of confounding variables (see Methods and Table

\begin{tabular}{|c|c|c|c|c|}
\hline \multirow{3}{*}{$\begin{array}{l}\text { Gado- } \\
\text { linium } \\
\text { Dose }\end{array}$} & \multirow{3}{*}{$\begin{array}{c}\text { No. } \\
\text { of } \\
\text { Patients }\end{array}$} & \multirow{2}{*}{\multicolumn{2}{|c|}{$\begin{array}{c}\begin{array}{c}\text { Serum Creatinine } \\
(\mathrm{mg} / \mathrm{dL})\end{array} \\
\text { Mean } \pm \mathrm{SD} \\
\text { (Minimum-Maximum) }\end{array}$}} & \multirow[b]{3}{*}{ Delta } \\
\hline & & & & \\
\hline & & Pre & Post & \\
\hline $.2-.29$ & 73 & $\begin{array}{c}2.23 \pm 1.62 \\
(.5-7.1)\end{array}$ & $\begin{array}{c}2.19 \pm 1.56 \\
(.6-7.0)\end{array}$ & $\begin{array}{c}-.04 \\
(-.7-.4)^{*}\end{array}$ \\
\hline $.3-.40$ & 37 & $\begin{array}{c}2.01 \pm 1.28 \\
(.7-6.2)\end{array}$ & $\begin{array}{c}1.96 \pm 1.20 \\
(.7-6.1)\end{array}$ & $\begin{array}{c}-.05 \\
(-.7-.4)^{*}\end{array}$ \\
\hline
\end{tabular}




\begin{tabular}{|c|c|c|c|c|c|c|}
\hline \multirow[b]{3}{*}{ Contrast Agent } & \multirow{3}{*}{$\begin{array}{l}\text { No. of } \\
\text { Patients }\end{array}$} & \multirow{2}{*}{\multicolumn{2}{|c|}{$\begin{array}{c}\text { Serum Creatinine }(\mathrm{mg} / \mathrm{dL}) \\
\text { Mean } \pm \mathrm{SD} \\
\text { (Minimum-Maximum) } \\
\end{array}$}} & \multirow[b]{3}{*}{ Delta } & \multirow[b]{3}{*}{$P$ Value } & \multirow{3}{*}{$\begin{array}{c}\text { Delta } \\
P \text { Value }\end{array}$} \\
\hline & & & & & & \\
\hline & & Pre & Post & & & \\
\hline $\begin{array}{l}\text { Gadopentetate } \\
\text { dimeglumine } \\
\text { Iodinated contrast }\end{array}$ & 21 & $\begin{array}{l}2.33 \pm 1.54 \\
(.7-5.7) \\
2.01 \pm 1.06 \\
(.8-4.7)\end{array}$ & $\begin{array}{l}2.26 \pm 1.47 \\
(.7-5.4) \\
2.66 \pm 2.03 \\
(.8-7.8)\end{array}$ & $\begin{array}{c}-.07 \\
(-.7-.4)^{*} \\
(-.65-5.6)^{*}\end{array}$ & $\begin{array}{l}.2 \\
.05\end{array}$ & .04 \\
\hline $\begin{array}{l}\text { Gadodiamide } \\
\text { Iodinated contrast }\end{array}$ & 37 & $\begin{array}{l}2.21 \pm 1.77 \\
(.6-7.1) \\
2.01 \pm 1.67 \\
(.6-7.1)\end{array}$ & $\begin{array}{l}2.12 \pm 1.68 \\
\quad(.7-7.0) \\
2.22 \pm 1.79 \\
\quad(.7-7.1)\end{array}$ & $\begin{array}{c}-.09 \\
(-.7-.3)^{*} \\
.21 \\
(-.3-2.9)^{*}\end{array}$ & $\begin{array}{l}.02 \\
.02\end{array}$ & .007 \\
\hline $\begin{array}{l}\text { Gadoteridol } \\
\text { Iodinated contrast }\end{array}$ & 6 & $\begin{array}{l}1.78 \pm .46 \\
(1.2-2.5) \\
1.8 \pm .51 \\
(1.2-2.5)\end{array}$ & $\begin{array}{l}1.81 \pm .47 \\
(1.2-2.6) \\
1.97 \pm .51 \\
(1.2-2.7)\end{array}$ & $\begin{array}{l}.03 \\
(-.1-.1)^{*} \\
.17 \\
(.0-.5)^{*}\end{array}$ & $\begin{array}{l}.36 \\
.13\end{array}$ & .25 \\
\hline $\begin{array}{l}\text { Total } \\
\text { Gadolinium contrast } \\
\text { Iodinated contrast }\end{array}$ & 64 & $\begin{array}{l}2.21 \pm 1.60 \\
(.6-7.1) \\
1.99 \pm 1.41 \\
(.6-7.1)\end{array}$ & $\begin{array}{l}2.14 \pm 1.53 \\
(.7-7.0) \\
2.34 \pm 1.80 \\
(.7-7.8)\end{array}$ & $\begin{array}{l}-.07 \\
(-.7-.4)^{*} \\
(-.35 \\
(-.6-5.6)^{*}\end{array}$ & $\begin{array}{l}.01 \\
.006\end{array}$ & .002 \\
\hline
\end{tabular}

\begin{tabular}{|c|c|c|c|c|c|c|c|}
\hline \multirow[b]{3}{*}{ Contrast Agent } & \multirow{3}{*}{$\begin{array}{c}\text { No. of } \\
\text { Patients }\end{array}$} & \multicolumn{6}{|c|}{ Serum Creatinine (mg/dL) } \\
\hline & & \multicolumn{3}{|c|}{ Gadolinium Contrast } & \multicolumn{3}{|c|}{ Iodinated Contrast } \\
\hline & & Pre & Post & Delta & Pre & Post & Delta \\
\hline $\begin{array}{l}\text { Gadolinium first } \\
\text { Iodine first }\end{array}$ & $\begin{array}{l}30 \\
34\end{array}$ & $\begin{array}{l}2.06 \\
2.34\end{array}$ & $\begin{array}{l}2.04 \\
2.22\end{array}$ & $\begin{array}{l}-.02 \\
-.12\end{array}$ & $\begin{array}{l}1.97 \\
2.01\end{array}$ & $\begin{array}{l}2.28 \\
2.39\end{array}$ & $\begin{array}{l}.31 \\
.38\end{array}$ \\
\hline Total & 64 & 2.21 & 2.14 & -.07 & 1.99 & 2.34 & .35 \\
\hline
\end{tabular}

1). None of the remaining 110 patients had any clinically significant change in renal function or evidence of toxicity after gadolinium. Overall, there was a minimal decrease in the mean serum creatinine level after high-dose gadolinium, as shown in Table $1(P<.01)$. This observation of a negligible change in serum creatinine was also made for each of the three gadolinium compounds examined independently of the other compounds. This effect was not dose-dependent, as shown in Table 2.

Sixty-four patients received both gadolinium and iodinated contrast on separate days. In these patients, there was a significant increase in serum creatinine after iodinated contrast compared with a negligible change after gadolinium contrast $(P<.01$; Table 3$)$. This observation was also made with each of the three gadolinium compounds analyzed separately and was statistically significant for gadopentetate dimeglumine and gadodiamide. The lower serum creatinine levels measured in these patients before iodinated contrast reflects the hydration and optimization of medical management performed before the iodinated contrast administration that was not performed before the MRI.

Table 4 shows these data from the 64 patients who received both gadolinium and iodinated contrast, categorized according to the order in which the contrast examinations were performed. Thirty patients received gadolinium first and with an interval between gadolinium and iodinated contrast ranging from 1 to 99 days (median, 7 days). Thirty-four patients received iodinated contrast first with an interval ranging from 1 to 598 days (median, 10 days). In eight patients, the interval was less than 2 days. Regardless of the order in which contrast agents were administered, there was a small decrease in serum creatinine after gadolinium and a substantial increase in serum creatinine after iodinated contrast.
When the patients were further broken down into subgroups who had pre-existing renal insufficiency with serum creatinine levels $>1.5 \mathrm{mg} / \mathrm{dL}$, the change in serum creatinine levels was even larger with the iodinated contrast, as expected (Table 5). The change with gadolinium was still negligible. For the patients with serum creatinine levels in excess of $1.5 \mathrm{mg} / \mathrm{dL}$, the incidence of contrast-induced renal failure was $29 \%$ with iodinated contrast (nine patients), compared with $0 \%$ for the gadolinium contrast agents. The effect of pre-existing renal insufficiency is further characterized in Table 6, which shows the patients' change in serum creatinine, stratified according to their baseline serum creatinine.

\section{- DISCUSSION}

Iodinated contrast-induced renal failure is estimated to occur in $.15 \%$ to $2 \%$ of all patients undergoing contrast imaging studies, including arteriograms, CT, and intravenous pyelography (16-19). Incidence is higher in patients with renal insufficiency, dehydration, multiple myeloma, diabetes, and advanced age. In most cases, the renal failure is short-lived, typically requiring several days of hospitalization with an eventual return to baseline renal function. But an estimated $5 \%$ to $10 \%$ of these patients never fully recover their baseline renal function.

These data in 64 patients who received both gadolinium and iodinated contrast demonstrate a significant increase in serum creatinine after iodinated contrast that was not seen with gadolinium contrast agents. In fact, there was a minimal decrease in serum creatinine after gadolinium contrast agents that presumably reflects the improved hydration from the saline given in combination with the gadolinium. This observation of less nephrotoxicity with gadolinium contrast agents was made using high doses of gadolinium (.2 to $.4 \mathrm{mmol} / \mathrm{kg})$ and in a pop- 


\begin{tabular}{|c|c|c|c|c|c|c|}
\hline \multirow[b]{3}{*}{ Contrast Agent } & \multirow{3}{*}{$\begin{array}{c}\text { No. of } \\
\text { Patients }\end{array}$} & \multirow{2}{*}{\multicolumn{2}{|c|}{$\begin{array}{c}\text { Serum Creatinine (mg/dL) } \\
\text { Mean } \pm \mathrm{SD} \\
\text { (Minimum-Maximum) }\end{array}$}} & \multirow[b]{3}{*}{ Delta } & \multirow[b]{3}{*}{$P$ Value } & \multirow[b]{3}{*}{ Delta $P$ Value } \\
\hline & & & & & & \\
\hline & & Pre & Post & & & \\
\hline $\begin{array}{l}\text { Gadopentetate } \\
\text { dimeglumine } \\
\text { Iodinated contrast }\end{array}$ & 10 & $\begin{array}{c}3.64 \pm 1.24 \\
(2.3-5.7) \\
2.88 \pm .87 \\
(1.8-4.7)\end{array}$ & $\begin{array}{l}3.50 \pm 1.20 \\
(2.2-5.4) \\
4.23 \pm 1.94 \\
(1.8-7.8)\end{array}$ & $\begin{array}{c}-.14 \\
(-.7-.4)^{*} \\
1.35 \\
(-.1-5.6)^{*}\end{array}$ & $\begin{array}{l}.22 \\
.045\end{array}$ & .037 \\
\hline $\begin{array}{l}\text { Gadodiamide } \\
\text { lodinated contrast }\end{array}$ & 17 & $\begin{array}{l}3.52 \pm 1.89 \\
(1.7-7.1) \\
3.07 \pm 1.99 \\
(.8-7.1)\end{array}$ & $\begin{array}{l}3.31 \pm 1.87 \\
(1.5-7.0) \\
3.45 \pm 2.04 \\
(.8-7.1)\end{array}$ & $\begin{array}{c}-.21 \\
(-.7-.1)^{*} \\
.38 \\
(-.3-2.9)^{*}\end{array}$ & $\begin{array}{l}.004 \\
.05\end{array}$ & .009 \\
\hline $\begin{array}{l}\text { Gadoteridol } \\
\text { Iodinated contrast }\end{array}$ & 4 & $\begin{array}{c}1.98 \pm .43 \\
(1.6-2.5) \\
2.05 \pm .42 \\
(1.5-2.5)\end{array}$ & $\begin{array}{c}2.00 \pm .43 \\
(1.6-2.6) \\
2.30 \pm .42 \\
(1.8-2.7)\end{array}$ & $\begin{array}{c}.02 \\
(-.1-.1)^{*} \\
.25 \\
(.0-.5)^{*}\end{array}$ & $\begin{array}{l}.64 \\
.13\end{array}$ & .19 \\
\hline $\begin{array}{l}\text { Total } \\
\text { Gadolinium contrast } \\
\text { Iodinated contrast }\end{array}$ & 31 & $\begin{array}{l}3.36 \pm 1.64 \\
(1.5-7.1) \\
2.88 \pm 1.57 \\
(.8-7.1)\end{array}$ & $\begin{array}{l}3.20 \pm 1.59 \\
(1.5-7.0) \\
3.56 \pm 1.93 \\
(.8-7.8)\end{array}$ & $\begin{array}{c}-.16 \\
(-.7-.4)^{*} \\
.68 \\
(-.3-5.6)^{*}\end{array}$ & $\begin{array}{l}.004 \\
.005\end{array}$ & .001 \\
\hline
\end{tabular}

\begin{tabular}{|c|c|c|c|c|c|c|}
\hline $\begin{array}{l}\text { Baseline Serum } \\
\text { Creatinine (mg/dL) }\end{array}$ & $\begin{array}{c}\text { No. of } \\
\text { Patients }\end{array}$ & Decrease & $\begin{array}{c}\text { No } \\
\text { Change }\end{array}$ & $\begin{array}{c}\text { Increase by } \\
<.25\end{array}$ & $\begin{array}{c}\text { Increase by } \\
.25-.5\end{array}$ & $\begin{array}{c}\text { Increase by } \\
>.5\end{array}$ \\
\hline $\begin{array}{l}<1.0 \\
1.0-1.5 \\
>1.5-2.5 \\
>2.5\end{array}$ & $\begin{array}{l}10 \\
23 \\
16 \\
15\end{array}$ & $\begin{array}{r}1 / 2 \\
8 / 6 \\
9 / 3 \\
11 / 1\end{array}$ & $\begin{array}{l}5 / 3 \\
9 / 8 \\
1 / 3 \\
2 / 3 \\
\end{array}$ & $\begin{array}{l}4 / 5 \\
4 / 6 \\
5 / 5 \\
1 / 1 \\
\end{array}$ & $\begin{array}{l}0 / 0 \\
2 / 3 \\
1 / 3 \\
1 / 4\end{array}$ & $\begin{array}{l}0 / 0 \\
0 / 0 \\
0 / 2 \\
0 / 6\end{array}$ \\
\hline
\end{tabular}

ulation of patients as opposed to normal volunteers. Analysis of the subgroup of patients with underlying renal insufficiency showed these gadolinium contrast agents to also be less nephrotoxic than iodinated contrast in this group of patients who are at greatest risk of contrast-induced renal failure. The absence of nephrotoxicity with gadolinium observed in this study did not require prehydration, mannitol, Lasix, or other special treatment, as is often performed with iodinated contrast administration.

Failure to observe any increase in serum creatinine after high-dose gadolinium contrast agents does not guarantee that gadolinium chelates are absolutely free of nephrotoxicity, because serum creatinine is not the most sensitive indicator of renal injury. However, it does suggest that any nephrotoxicity that may be present is not clinically important at these gadolinium doses. The possibility of other toxicity from gadolinium chelates must also be considered $(21,22)$. Transient elevation of liver enzymes has been reported in data from safety trials (23). There is also the theoretical possibility of heavy metal toxicity occurring if gadolinium dissociates from the chelator. In clinical practice, however, these other toxicities have not been reported, even in patients with delayed excretion of gadolinium caused by renal insufficiency (14). Dialysis should still be considered if a patient develops any signs of toxicity; it was not required in any of the patients in this study.

Because the gadolinium chelates have similar pharmacokinetics and enhancement patterns as iodinated contrast, it is possible to reduce the risk of contrast-induced renal failure by substituting gadolinium-enhanced MRI examinations for iodinated contrast-enhanced CT scans and angiograms. Use of gadolinium in place of iodinated contrast has also been reported in conventional angiography (24) and CT (25). The high atomic weight of gadolinium makes it comparably radiopaque as iodinated contrast (iodine atomic weight $=127$, k-edge $=33 \mathrm{keV}$; gadolinium atomic weight $=157, \mathrm{k}$-edge $=52 \mathrm{keV}$ ). The gadolinium chelates studied herein have a low incidence of adverse events and, in particular, severe allergic reactions are extremely rare $(26,27)$. This also contributes to increased safety of gadolinium, compared with iodinated contrast.

The retrospective nature of this study introduced several biases that represent significant limitations. The population was limited to patients who were having daily serum creatinine measurements at the time of MRI. This heavily weighted the population toward inpatients and patients with underlying renal insufficiency. In general, inpatients tend to be sicker than outpatients. Limiting the study to patients who received high-dose gadolinium biased the study population toward patients with cardiovascular disease, because high-dose gadolinium is only used for MR angiography at our institution. Although these are significant biases, these data corroborate other reports on the absence of observable nephrotoxicity with these gadolinium contrast agents (3-14). Taken together, the argument for substituting gadolinium-enhanced MRI examinations for iodinated contrast-enhanced examinations to decrease the risk of nephrotoxicity is compelling.

Acknowledgments: We thank Jennifer Ward for assistance with data acquisition and analysis; Drs. Dasika Narasimham. Kyung Cho, John Kaufman, Alex Aisen, Bruce Rosen, and Tom Brady for many helpful suggestions; and Karen Travis for assistance with preparation of the manuscript.

\section{References}

1. Harpur ES, Worah D, Hals, P, Holtz E, Furuhama K, Nomura H. Preclinical safety assessment and pharmacokinetics of gadodiamide injection, a new magnetic resonance imaging contrast agent. Invest Radiol 1993; 28:S28-S43.

2. Leander P, Allard M, Caille JM, Golman K. Early effect of gadopentate and iodinated contrast media on rabbit kidneys. Invest Radiol 1992; 27:922-926. 
3. Carvlin MJ. DeSimone DN, Meeks MJ. Phase II clinical trial of gadoteridol injection, a low-osmolal magnetic resonance imaging contrast agent. Invest Radiol 1992; 27:S16-S21.

4. Goldstein HA, Kashanian FK, Blumetti RF, Holyoak WL, Hugo FP. Blumenfield DM. Safety assessment of gadopentetate dimeglumine in U.S. clinical trials. Radiology 1990; 174:17-23.

5. Haustein J, Niendorf HP, Krestin G, et al. Renal tolerance of gadolinium-DTPA/dimeglumine in patients with chronic renal failure. Invest Radiol 1993; 27:153-156.

6. Lufkin RB. Severe anaphylactoid reaction to Gd-DTPA fletter to the editor). Radiology 1990; 176:879.

7. Lundby B, Berg KJ. Lien HH, Aamdal S. A double blind study to evaluate the tolerability of gadodiamide injection and its effect on renal function in patients undergoing cerebral magnetic resonance imaging. Br J Radiol 1993; 66:871-876.

8. Nlendorf HP, Dinger JC, Haustein J, Cornelius I, Alhassan A, Clauss W. Tolerance data of Gd-DTPA: a review. Eur J Radiol $1991 ; 13: 15-20$.

9. Niendorf HP, Haustein J, Cornelius I, Alhassan A, Clauss W. Safety of gadolinium-DTPA: extended clinical experience. Magn Reson Med 1991; 22:222-228.

10. Niendorf HP, Haustein J, Louton T, Beck W, Laniado M. Safety and tolerance after intravenous administration of $0.3 \mathrm{mmol} / \mathrm{kg}$ Gd-DTPA. Results of a randomized, controlled clinical trial. Invest Radiol 1991; 26:S221--S223.

11. Rofsky NM, Weinreb JC, Bosniak MA, Libes RB, Birnbaum BA. Renal lesion characterization with gadolinium-enhanced MR imaging: efficacy and safety in patients with renal insufficiency. Radiology 1993; 180:85-89.

12. Runge VM, Bradley WG, Brant-Zawadzki MN, et al. Clinical safety and efficacy of gadoteridol: a study in 411 patients with suspected intracranial and spinal disease. Radiology 1991; 181: 701-709.

13. Schuhmann-Giampieri G, Krestin G. Pharmacokinetics of GdDTPA in patients with chronic renal failure. Invest Radiol 1991; 26:975-979.

14. Rofsky NM, Weinreb JC, Bosniak MA, Libes RB, Birnbaum BA. Renal lesion characterization with gadolinium-enhanced
MR imaging: efficacy and safety in patients with renal insuffciency. Radiology 1991; 180:85-89.

15. Runge VM, Kirsch JE, Thomas GS. High-dose applications of gadolinium chelates in magnetic resonance imaging. Magn Reson Med 1991; 22:358-363.

16. Prince MR. Gadolinium-enhanced MR Aortography. Radiology 1994: 191:155-164.

17. Arrigo G, Cavaliere G, Scalia A, et al. Radiocontrast media nephrotoxicity: clinical aspects. Contrib Nephrol 1987; 55:176188.

18. Katayama $H$, Yamaguchi $K$, Kozuka $T$, Takashima $T$, Seez $P$, Matsuura $K$. Adverse reactions to lonic and nonionic contrast media: a report from the Japanese Committee on the Safety of Contrast Media. Radiology 1990; 175:621-628.

19. Parfrey PS, Griffiths SM, Barrett BJ, et al. Contrast materialinduced renal failure in patients with diabetes mellitus, renal insufficiency, or both: a prospective controlled study. N Engl J Med 1989: 320:143-149.

20. Schwab SJ, Hlatky MA, Pieper KS, et al. Contrast nephrotoxicity: a randomized controlled trial of a nonionic and an ionic radiographic contrast agent. N Engl J Med 1989; 320:149-153.

21. Rocklage SM, Worah D, Kim S. Metal ion release from paramagnetic chelates: what is tolerable? Magn. Reson. Med. 1991 21:216-221.

22. Oksendal AN, Hals P. Biodistribution and toxicity of MR contrast media. JMRI 1993; 3:157-165.

23. Berlex Laboratories, Inc. Package insert: Magnevist injection (brand of gadopentetate dimeglumine). Wayne, NJ: Berlex Laboratories, Inc., 1988.

24. Kinno Y, Odagiri K, Andoh K, Itoh Y, Tarao K. Gadopentetate dimeglumine as an alternative contrast material for use in angiography. Am J Roentgenol 1993; 160:1293-1294.

25. Quinn AD, O'Hare NJ, Wallis FJ, Wilson GF. Gd-DTPA: an alternative contrast medium for CT. J Comput Assist Tomogr 1994; 18:634-636.

26. Weiss KL. Severe anaphylactoid reaction after IV Gd-DPTA. Magn Reson Imaging 1990; 8:817-818.

27. Jordan RM, Mintz RD. Fatal reaction to gadopentetate dimeglumine. Am J Roentgenol 1995; 164:743-744. 